\title{
Inhalt, Vol. 9, No. 1, 1986
}

\section{Contents}

Impressum 2

Editorial 4

Kneba, M.; Krieger, G.; Brocke, U.; Bolz, I. und

Krönke, M., Göttingen

Rearrangements von Immunglobulin- und T-Zell-Anti-

genrezeptor-Genen als diagnostische Marker bei lympha-

tischen Neoplasien 6

Leserzuschriften $\quad 10$

Mezger, J.; Lamerz, R.; Arnholdt, H.; Huhn, D. und Wilmanns, W., München

Tumormarker in der Diagnostik von Aszites- und Pleura-

punktaten 11

Ziegler, G. und Müller, F. , Stuttgart

Zur Prävalenz und Ätiologie psychischer Probleme bei

Tumorpatienten 18

Hoffmanns, H. W. und Altmeier, G., Mönchengladbach

Lokale Applikation von Mitoxantron beim inoperablen, stenosierenden Oesophaguskarzinom. - Vorläufige Mitteilung 27

Irene Boll, Berlin

Die Wirkung verschiedener Glukokortikoide auf die Zellkinetik der menschlichen Hämatopoese in vitro, dargestellt an der Knochenmarkkultur und an der mit Phytohämagglutinin und Pokeweed Mitogen stimulierten Blutkultur 30

Lellé, R. J.; Heidenreich, W. und Peter, H. H., Hannover Charakterisierung lymphoider Zellen durch monoklonale Antikörper bei Patientinnen mit gynäkologischen Karzinomen 36

Neuigkeiten für die klinische Praxis 40

Seibel, R. M. und Wendt, B. K., Wiesbaden

Immunglobuline zur Prophylaxe der Strahlenpneumonitis nach großvolumiger Bestrahlung beim Bronchialkarzi-

nom 43

Weitensfelder, W.; Redtenbacher, M.; Ott, K. und

Sabitzer, H., KlagenfurtlÖsterreich

Erfahrungen mit der intraoperativen Radiotherapie beim inoperablen Pankreaskarzinom 
Onkologie-Mitteilungen Valet

Hinweise für Autoren 56

Sonderbände 56

Imprint 2

Editorial 4

Kneba, M.; Krieger, G.; Brocke, U.; Bolz, I. and

Krönke, M., Göttingen

Immunoglobulin and T-Cell Antigen Receptor Gene

Rearrangements as Diagnostic Markers in Lymphoid

Neoplasms 6

Letters to the Editors 10

Mezger, J.; Lamerz, R.; Arnholdt, H.; Huhn, D. and

Wilmanns, W., München

Tumor Markers in Diagnosis of Serous Effusions 11

Ziegler, G. and Müller, F., Stuttgart

Prevalence and Etiology of Psychic Problems in Cancer

Patients 18

Hoffmanns, H. W. and Altmeier, G., Mönchengladbach

Local Application of Mitoxantrone in the Treatment of

Inoperable, Stenosing Oesophageal Carcinoma $\quad 27$

Irene Boll, Berlin

The Effect of Different Glucocorticoids on the Kinetics of

the Human Haematopoietic Precursor Cells in Vitro,

Represented by Means of the Bone Marrow Culture and

of the Blood Cell Culture Stimulated with Phytohaemag-

glutinine and Pokeweed Mitogen 30

Lellé, R. J.; Heidenreich, W. and Peter, H. H., Hannover

Determination of Lymphoid Cells in Patients with Gyne

cologic Malignancies by Monoclonal Antibodies 36

News for Clinical Practice 40

Seibel, R. M. and Wendt, B. K., Wiesbaden Immunoglobulins for Prophylaxis of Radiation

Pneumo-nitis after Extended Field Irradiation of Lung Cancer. . . 43

Weitensf elder, W.; Redtenbacher, M.; Ott, K. and

Sabitzer, H., Klagenfurtl Austria

Experiences in Intraoperative Electron Beam Irradiation

for Unresectable Pancreatic Carcinoma

48

Notice to Oncology Communications 54

Instructions for Authors 56

Special Editions $\quad 56$

Bibliographischer Hinweis: Inhaltsverzeichnisse dieser Zeitschrift erscheinen regelmäßig in current contents ${ }^{\circledR}$ sowie in anderen bibliographischen Diensten. 